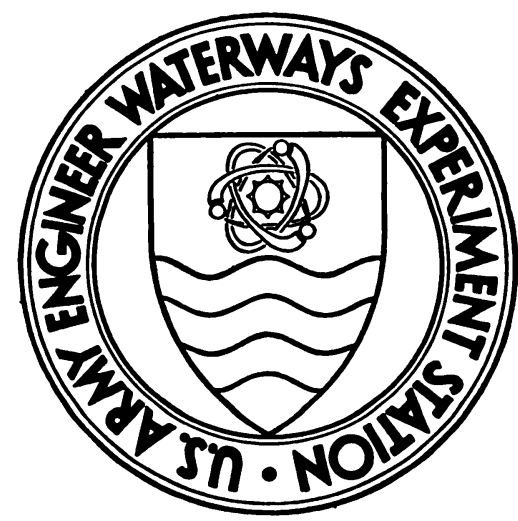

MISCELLANEOUS PAPER S-73-8

\title{
EVALUATION OF GOODYEAR MEDIUM-DUTY ALUMINUM HONEYCOMB LANDING MAT
}

by

G. L. Carr

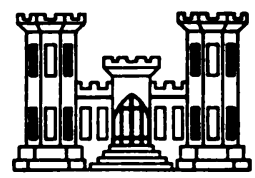

March 1973

Sponsored by U. S. Army Materiel Command

Project No. 1G664717DHOI-10

(Formerly 1G664717D556-0l)

Conducted by U. S. Army Engineer Waterways Experiment Station

Soils and Pavements Laboratory

Vicksburg, Mississippi 